\title{
Postnonclassical Paradigm of Ergonomic DESIGN OF COMPLEX SYSTEMS
}

\author{
Oleg Ipatov \& Sergey Sergeev
}


This Publication has to be referred as: Ipatov, O[leg] \& Sergeev, S[ergey] (2017). Postnonclassical Paradigm of Ergonomic Design of Complex Systems, Proceedings of the 28th DAAAM International Symposium, pp.1108-1110, B. Katalinic (Ed.), Published by DAAAM International, ISBN 978-3-902734-11-2, ISSN 1726-9679, Vienna, Austria DOI: $10.2507 / 28$ th.daaam.proceedings. 154

\begin{abstract}
The article discusses the problems of engineering-psychological design, automated systems design, including virtual prototyping and polyparametric optimization. We have considered the prospects of applying post-non-classical models of complex systems for the analysis of interactions between the operator and the design system with artificial intelligence.
\end{abstract}

Keywords: complex systems; self-organization; communication; environment and engineering design environment

\section{Introduction}

Methods and technologies of designing complex technical systems, their maintenance, optimization and automation of project management are classical objects not only in engineering sciences, but they also define the key problems of engineering psychology [1]. Their study is devoted to the works of prominent representatives of the technical direction the engineering and psychological knowledge (Galaktionov, A.I., Gubinskiy, A.I., Koroteev, G.L., Krylov A.A., Lvov V.M., Lomov B.F., Naftaliev A.I., Paderno P.I., Chernyshev A.P., Shadrikov V.D., Shchedrovitsky L.P., etc.). The general conclusion obtained in their work is that individual human consciousness is able to create objects and systems of high complexity, their implementations do not meet the criteria of optimality in the power of biologically determined limitations of the human cognitive system that performs on the associative principle, precluding the exact knowledge. The possibility of collective action in implementing complex projects is much higher, but takes a long time to form the team and its constitutive communication. On average, the creation of the effective team for technical complexes and systems takes at least 10-15 years. The only reasonable way to deal with this situation is automation of design activities that reduce the cognitive load on a person. However, there is a risk of a new problem - ensuring an efficient symbiotic interaction between a designer (design group) and a virtual simulation environment, transforming product ideas into physical product and its optimization. This problem cannot be solved only by creating touch interfaces; it is important and effective to combine the human cognitive system with the design environment. Unfortunately, the scientific solution to this problem is, currently unavailable.

The fact that scientists turn to new forms of scientific rationality, which operates in a complex and evolving systems, is not accidental. This is quite a reasonable reaction to the crisis of modern methodology of designing complex technical systems and complexes that have exhausted their possibilities within the framework of classical mechanistic ideas, which 
do not allow creating an artificial system of organized complexity [2,3]. The main problem is the necessity to work with high-precision polyparametric models of physical systems.

Turning to cyber-physical systems, "industry 4.0" technology and bionic design technologies (bionic design) is a consequence of dealing with complexity in creating modern engineering products [4].

Developing a new class of engineering instruments provide computer-aided design in a virtual environment along, with the translation of virtual products in the real physical world using technologies and platforms CAD/CAE/CAM/PLM [5]. Their emergence at the forefront of science and technology is determined by the needs of practice and the evolution of the man-made environment of human civilization.

Development processes, technological environment, tools and principles of its generation in the last decade have become global [6]. We were completely unarmed in front of the new reality related to the emergence of complex network systems, implementing functions of artificial intelligence, interacting with a natural intelligence. Complex systems are a special class of systems. The purpose of this study is to develop a paradigm of ergonomic design of complex systems on a new stage of development, technological environment. It will require a paradigm shift for the technical design, the use of the new categorical apparatus, including interdisciplinary discourses generated in humanities, biology, neurophysiology, genetics, etc. But this is not enough. More profoundly we mean changing the scientific picture of the world, emergence of the new philosophy that reflects the laws of forming a complex world beyond the limits of ordinary consciousness, operating within the framework of classical models of rationality [7].

\section{The problem of design complexity in developing systems}

The problem of designing complex systems cannot be solved without the introduction of categorical forms, reflecting the significant features of this class. In the modern scientific and psychological knowledge on mental and personality regulation of constituent entities of the project activity (Abulkhanova-Slavske K.A., Antsiferova L.I., Bodrov V.A., Zavalova N.D., Zhuravlev A.L., Lomov B.F., Oboznov A.A., Oshanin D.A., Ponomarenko V.A., Sergienko E.A., etc.) the personal, the subjective component is crucial in forming a specialist and it opportunities in the ergatic system. According to the subject-activity approach (Rubinstein S.L., Anan'ev B.G., Leontiev A.N., Lomov B.F, Brushlinsky A.V., Klimov E.A., etc.), human involvement in the labor activity forms a specific property and a quality of self-organization, self-regulation, self-affirmation and self-control, coordination of external and internal conditions and activities.

Cyclical interaction of developers with the virtual environment while solving a design problem is not a guarantee of order in a complex system of disordered, chaotically mixed potential ideas of the future product. The fact of "advance notice" is long known in psychology; it is formulated in the famous aphorism of Marx that the worst architect from the best bees is innately characterized by the ability to build the wax cell in the head, before building it in reality. In order words, the result of labor is pre-imagined, or pre-planned in the mind.

Designing in virtual reality a human with freedom to choose options for a project (product) and supercomputing and modeling of the design system provide physical implementation.

\section{Communication in smart design environment}

Communication processes in the system design are considered within the classical approach as the exchange of information between human and machine parts of the system, but the modern post-non-classical views on communication emphasize its self-organizing nature, subordinating "subject-quasisubjectivity" relations [8]. In the design system there are subjects of design and means of interaction between them and simulation environments. The designer is aware of a problematic situation in developing a complex simulation environment and then work with the intelligence of the symbiotic environment to make a decision on its settlement. There is used an interactive method of in which the environment responds flexibly to actions of the designer shaping the design discourse in the form of optimized solutions, which results into the final version. The next stage is to form the "integration platform" that contains the recognized and shared (by all the designers) knowledge about the problem, which needs solving. The Analysis of the processes occurring in the supercomputing system design, in our opinion, is possible with the introduction of the description of the intrasystem communication in terms of the paradigm of second order Cybernetics (Heinz von Foerster, Humberto Maturana, Francisco Varela, Sokolov B.V., and Yusupov R.M.) [9-14]. This approach allows solving the classical problem of searching sources of order in self-organizing systems (including in ergonomics design). It is logical, in our opinion, to use reflective models in developing network systems and group design (Lepsky, V.E., and Lefevre V.A.) [15-17]. In the system aspect, reflection is implied as the ability of some systems to build models themselves and other systems, and simultaneously to see themselves building such models. In this way, it is possible to draw a line between structural differences of human knowledge about himself and awareness of being a bearers of such knowledge, which is important in transforming subjective models into their physical embodiment.

\section{Conclusion}

We set out the basic content of the non-classical paradigm of ergonomic design of complex systems. Automation project activities focus the attention of researchers on using non-conventional methods for interdisciplinary synthesis and close cooperation of representatives of humanitarian and technical knowledge, when creating computer-aided design of. 
This is especially important when creating complex ergonomics and socio-technical systems with integrated artificial intelligence that gets into a symbiotic relationship with the intelligence and experience of the designer. The following work will be devoted to communication in complex systems.

\section{Acknowledgments}

The work is fulfilled within the implementation of the State Assignment from the Ministry of Education and Science of the Russian Federation No. 25.8444.2017/БЧ for the project "Engineering and psychological design of simulation training systems based on symbiotic polymodal technogenic environments".

\section{References}

[1] Sergeev, S.F. (2011). Introduction to engineering psychology and ergonomics immersive environments, SaintPetersburg, Russia

[2] Sergeev, S.F. (2012). The Problem of difficulty in ergatic systems. In: materials of the conference "Control in technical, ergatic, organizational and network systems" (UTEOS-2012), pp. 802-805, "Concern "CRI "Electropribor" SPb., Saint-Petersburg, Russia

[3] Sergeev, S.F. (2014). Methodological problems in the design of complex ergatic systems. Problems of control and modeling in complex systems: proceedings of the XVI International conference (30 June - 03 July 2014 Samara, Russia) / edited by: Acad. E.A. Fedosov, Acad. N.A. Kuznetsov, Professor V.A. Wittikh, pp. 386-392, Samara scientific centre of RAS, ISBN 978-5-93424-703-5, Samara, Russia

[4] Sergeev, S.F. (2013). Global, technological environment in the evolution of human civilization. Bulletin of Moscow University Witte. Series 1: Economics and management, No. 1, pp. 80-86.

[5] Sergeev, S.F. (2015). Ergonomics and engineering psychology, man-made world: issues of methodology, theory and practice. In: Modern trends in psychology of labor and organizational psychology, L.G. Dikaja, A.L. Zhuravlev, A.N. Zankovskiy, (Ed.), pp. 47-56, Publishing house "Institute of psychology RAS", ISBN 978-5-9270-0303-7, Moscow, Russia

[6] Sergeev, S.F. (2013). Science and Technology of the 21st Century. Communications and NBICS-Convergence. In.: Global Future 2045/ Convergence Technologies (NBICS) and Trans-Humanistic Evolution. Edited by Prof. D.I. Dubrovsky, pp. 158-168, OOO "Izdatelstvo MBA", ISBN 978-5-906325-26-6, Moscow

[7] Stepin, V.S. (2009). Classics, Non-Classics, Post Non-Classics: Criteria for Differentiation, In: Post Non-Classics: Philosophy, Science, Culture, pp. 249-295, Publishing House "Mir", ISBN 5988460372, 9785988460374, St. Petersburg

[8] Sergeev, S.F. \& Sergeeva, A.S. (2014). Educational communication and interface in computer education systems and media, Open education, Vol. 106, No. 5, pp. 41-48, ISSN 1818-4243, Moscow, Rusia

[9] Maturana, H. \& Varela, F. (2001). The Tree of Knowledge, Progress-Traditsia, 2001. ISBN 5-89826-103-6, Moscow, Russia

[10] Knyazeva, E.N. (2006). Epistemological Constructivism, Philosophy of Science. Issue 12, pp. 133-152, Moscow: IF RAS, ISSN 1560-7488, Moscow, Russia

[11] Tsokolov, S. (2000). Discourse of Radical Constructivism. Traditions of Scepticism in Modern Philosophy and Theory of Cognition, PHREN, ISBN 3-9805074-2-4, Munich

[12] Sergeev, S.F. (2009). Teaching and Professional Immersive Environments, Narodnoie Obrazovanie, ISBN 978-587953-256-2, Moscow, Russia

[13] Grgurevic, I; Perakovic, D; Forenbacher, I \& Milinovic, T. (2015). Application of the Internet of Things Concept in Carsharing System, Chapter 34 in DAAAM International Scientific Book 2015, pp.401-414, B. Katalinic (Ed.), Published by DAAAM International, ISBN 978-3-902734-05-1, ISSN 1726-9687, Vienna, Austria

[14] Vaupotic, B.; Brezocnik, M. \& Balic, J. (2007). Use of Self-Organizing Neural Network in Modern Manufacturing Systems, Chapter 12 in DAAAM International Scientific Book 2007, B. Katalinic (Ed.), Published by DAAAM International, ISBN 3-901509-60-7, ISSN 1726-9687, Vienna, Austria

[15] Arshinov, V.I. (2015). The reflexivity paradigm of complexity. Reflexive processes and control. The collection of materials of the X International Symposium on October 15-16, 2015, pp. 86-88. ISBN 978-5-89353-465-8, SaintPetersburg, Russia

[16] Lepsky, V.E. From monodisciplinary to transdisciplinary approach in the development of scientific knowledge (perspective control). The collection of materials of the X International Symposium on October 15-16, 2015, pp. 713. ISBN 978-5-89353-465-8, Saint-Petersburg, Russia

[17] Buchmeister, B.; Leber, M.; Palcic, I. \& Vujica - Herzog, N. (2013) Future Development Trends and Challenges in Production and Social Systems, Chapter 04 in DAAAM International Scientific Book 2013, pp. 111-132, B. Katalinic \& Z. Tekic (Eds.), Published by DAAAM International, ISBN 978-3-901509-94-0, ISSN1726-9687, Vienna, Austria 